\section{ANALISIS PERSEPSI KINERJA PELAYANAN SEKOLAH BINA BHAKTI KABUPATEN KUBU RAYA}

\author{
Juliahir Barata ${ }^{1}$, Udin Rinaldi \\ juliahir@yahoo.com¹ ; siguntang@ymail.com
}

Tax payers satisfaction, Compliance tax payer

\begin{abstract}
Survey research was conducted at Sekolah Bina Bhakti Kabupaten Kubu Raya with descriptive method. Variables consist of service performance that is limited to 5 (five) dimensions, namely reliability; responsiveness; guarantee; empathy; and manifestations. The main priority dimension of research variables is considered important to note, because the services undertaken by institutions have not been in accordance with the wishes of stakeholders. Therefore, the institution should do business so that user satisfaction can be achieved. Based on cartesian diagram mapping, the variables dimension is the ability of the officer to respond quickly to complaints, ease / speed in service, attention of officer to the complaint, ease in fulfilling the desire of service user. While low priority is considered important in the variable dimension of the flexibility of payment time in case of delay.
\end{abstract}

Keywords: Service performance

\title{
PENDAHULUAN
}

Prosedur dan etika pelayanan yang berkembang dalam birokrasi sangat jauh dari nilai-nilai dan praktik yang menghargai individu sebagai warga negara yang berdaulat. Prosedur pelayanan, misalnya, tidak dibuat untuk mempermudah pelayanan, tetapi lebih untuk melakukan kontrol terhadap perilaku, sehingga prosedurnya berbelit-belit dan rumit. Tidak hanya itu, mulai masa orde baru hingga kini, eksistensi pelayan publik merupakan jabatan terhormat yang begitu dihargai tinggi dan diidolakan, sehingga sebagai pelayan publik (publik servant) dalam arti riil menghadapi kendala untuk direalisasikan. Hal ini terbukti bahwa mereka siap dilayani bukan siap untuk melayani.

Permasalahan utama pelayanan publik pada dasarnya berkaitan dengan peningkatan kualitas pelayanan itu sendiri. Pelayanan yang berkualitas sangat tergantung pada berbagai aspek, yaitu bagaimana pola penyelenggaraannya (tata laksana), dukungan sumber daya manusia, dan kelembagaan serta adanya konsep yang jelas. Dilihat dari sisi pola penyelenggaraannya, pelayanan publik masih memiliki berbagai kelemahan antara lain : 1) Kurang responsive, kondisi ini terjadi pada hampir semua tingkatan unsur 
Service performance

pelayanan, mulai pada tingkatan petugas pelayanan (front line) sampai dengan tingkatan penanggungjawab instansi. Respon terhadap berbagai keluhan, aspirasi, maupun harapan pengguna seringkali lambat atau bahkan diabaikan sama sekali; 2) Kurang informative, berbagai informasi yang seharusnya disampaikan lambat atau bahkan tidak sampai kepada pengguna; 3) Kurang accessible, berbagai unit pelaksana pelayanan terletak jauh dari jangkauan masyarakat, sehingga menyulitkan bagi mereka yang memerlukan pelayanan tersebut; 4) Kurang koordinasi, berbagai unit pelayanan yang terkait satu dengan lainnya sangat kurang berkoordinasi. Akibatnya, sering terjadi tumpang tindih ataupun pertentangan kebijakan antara para instansi pelayanan dengan instansi pelayanan lain yang terkait; 5) Birokratis pelayanan, pada umumnya dilakukan melalui proses yang terdiri dari berbagai level, sehingga menyebabkan penyelesaian pelayanan yang terlalu lama; 6) Kurang mau mendengar keluhan, saran, dan aspirasi. Akibatnya pelayanan dilaksanakan dengan apa adanya, tanpa ada perbaikan dari waktu ke waktu; dan 7) Inefisien, berbagai persyaratan yang diperlukan, khususnya dalam pelayanan seringkali tidak relevan dengan pelayanan yang diberikan.

Dalam bidang pendidikan, bahwa pembangunan sumber daya manusia mempunyai peranann yang sangat penting bagi kesuksesan dan keseimbangan pembangunan nasional yang telah digariskan, pembangunan serta peningkatan kualitas sumber daya manusia merupakan prioritas yang harus diperhatikan dan dirancang sedemikian rupa serta berdasarkan pemikiran yang matang untuk mengimbangi lajunya perkembangan ilmu pengetahuan dan teknologi informasi.

Pendidikan memiliki peranan yang sangat vital serta merupakan suatu wadah yang sangat tepat di dalam upaya peningkatan kualitas sumber daya manusia serta harus menjadi prioritas secara optimal dan berkesinambungan, agar kualitas peserta didik pada jenjang pendidikan dasar yang merupakan pondasi untuk jenjang pendidikan lebih tinggi benar-benar berkualitas serta memiliki kompetensi yang tinggal mematangkan setelah peserta didik yang bersangkutan pada jenjang pendidikan berikutnya, sehingga terlihat dengan jelas ada kesinambungan antara jenjang pendidikan tingkat sekolah dasar dengan tingkat pendidikan sekolah menengah pertama, dan seterusnya.

Keberhasilan dalam pembangunan pendidikan nasional ditentukan oleh kualitas gurunya serta perangkat sekolah yang bertindak sebagai sumber daya manusia, sebagai roda penggerak tingkat keberhasilan pembangunan, sekolah dalam hal ini termasuk 
perangkat sistem di dalamnya adalah merupakan pengambil keputusan, penentu kebijakan, perancang, pemikir, perencana juga pelaksana terdepan sebagai pelaku control

Service

performance segaligus pengamat serta pengawas pembangunan dalam bidang pendidikan.

Pada dasarnya peningkatan mutu pendidikan harus dimulai dengan peningkatan mutu pendidikan pada sekolah dasar, mengingat pendidikan sekolah dasar merupakan pondasi untuk pengembangan ke jenjang pendidikan menengah pertama juga pada jenjang pendidikan selanjutnya, akan lebih baik dan lebih sempurna lagi, apabila orang tua berinisiatif menyekolahkan anak-anaknya yang dimulai dari pendidikan taman kanak-kanak, maka akan lebih efektif lagi dalam pengembangannya ketika peserta didik berada pada pendidikan dasar. Pada Jenjang pendidikan dasar, merupakan bentuk satuan pendidikan yang sangat urgen keberadaannya, dalam hal ini seorang anak tanpa menempuh sekolah pendidikan dasar maka yang bersangkutan tidak akan bisa melanjutkan ke jenjang pendidikan yang lebih tinggi.

\section{Permasalahan dan Tujuan}

Demikian pula halnya dengan penyelenggara pendidikan swasta, untuk melihat kinerja pelayanan kepada peserta didik pada Sekolah Bina Bhakti Kabupaten Kubu Raya dalam menyelenggarakan pendidikannya. Tujuannya adalah untuk mengetahui presepsi peserta didik terhadap kinerja pelayanan Sekolah Bina Bhakti Kabupaten Kubu Raya. Sementara penelitian membatasi kinerja pelayanan jasa pada 5 (lima) dimensi yaitu keandalan ; daya tanggap ; jaminan ; empati ; dan keberwujudan. (Kotler dalam Lupiyoadi, 2001:148).

\section{LANDASAN TEORITIS}

Keberhasilan peserta didik dalam menempuh pendidikan pada jenjang pendidikan selanjutnya sangatlah ditentukan oleh standar kompetensi pada jenjang pendidikan dasar, dengan demikian jelas, pemerintah dalam hal ini harus benar-benar tanggap, agar senantiasa melakukan terobosan-terobosan untuk mengembangkan kompetensi yang harus dikuasai oleh guru sekolah dasar, hal ini dimaksudkan agar cita-cita yang ingin di capai untuk peningkatan mutu pendidikan dapat terwujud sesuai yang tertuang di dalam tujuan pendidikan nasional. 
Service performance

030
Keberhasilan sebuah lembaga pendidikan yang dalam hal ini adalah sekolah tidak lepas dari kemampuan yang professional dari pimpinan dalam mengendalikan perangkat di dalamnya dengan komitmen pada tugas pokok dan fungsi, mengingat pimpinan yang baik adalah seseorang yang tahu kecakapan yang dimiliki oleh mitra kerjanya sehingga yang bersangkutan tahu memposisikan harus dimana anak buahnya di tempatkan sesuai dengan keakhlian yang dimilikinya, maka untuk yang bersangkutan juga dapat dikatakan sebagai pimpinan yang professional. Pendidikan sekolah dasar, mengemban misi sebagai lembaga pendidikan yang menyelenggarakan proses pembelajaran yang merupakan pondasi bagi peserta didik usia dasar, guru sebagai mengemban tugas memberikan bekal sebagai kemampuan dasar sehingga peserta didik siap dan layak untuk melanjutkan pendidikan ke jenjang pendidikan yang lebih tinggi.

Peran masyarakat sekolah tidak terlepas dari orang tua siswa yang bertindak sebagai subyek pelaku, pada posisinya ketika sekolah banyak melibatkan orang tua siswa, manakala sekolah menerapkan kebijakan-kebijakan yang harus dijalankan, dan dibuat orang tua untuk mengerti tentang program sekolah yang harus dijalankan maka pihak sekolah akan mendapat banyak kemudahan dimana ketika orang tua secara prosedur sudah paham benar program-program sekolah yang harus dijalankan, maka peran serta orang tua yang tersangkut finansial turut andil menjadi bagian yang berperan serta aktif turut membangun pendidikan ini agar berjalan dengan maksimal, dan tanpa kendala yang berarti. Peran serta aktif orang tua siswa, sangat menunjang kelangsungan pelaksanaan program-program sekolah yang akan dilaksanakan minimal diperlukan sekurang-kurangnya enam kali pertemuan dengan orang tua dalam satu tahunnya, dengan demikian akan mempermudah bagi sekolah didalam mengambil keputusan-keputusan yang akan dijalankan karena adanya partisipasi masyarakat dalam kapasitas orang tua dari peserta didik yang di sekolahkan pada sekolah tersebut.

Peran peserta didik sebagai subyek belajar adalah individu yang terdiri dari berbagai karakter, adat istiadat, lingkungan social, cara mendidik orang tua juga pariatif, dengan tingkat daya nalar serta kecerdasan yang tentu saja berbeda, dan hal ini merupakan acuan serta sebagai bahan pertimbangan bagi guru untuk lebih mengenal lagi keberadaan peserta didik sebagai individu dengan cirri-ciri seperti ; dalam hal ini peserta didik sebagai makhluk social tidak terlepas dari perilaku yang baik dan buruk, satu sisi lingkungan adalah penentu tingkah laku bagi peserta didik secara individu yang 
merupakan pengalaman dari kemampuan untuk bergaul yang dipelajari, dengan demikian peserta didik adalah merupakan titik sentral dari target atau rancang bangun

Service performance sistem yang akan dijalankan.

Guru sebagai tenaga kependidikan yang profesional dan mendapat kepercayaan penuh dari masyarakat sebagai figur dari seseorang yang memiliki segudang prestasi dengan sejumlah ilmu pengetahuannya dalam artian guru adalah gudangnya ilmu dan kepercayaan itu berlaku sampai akhir hayat. Seseorang dengan sebutan guru tidak cukup hanya menguasai materi pelajaran saja, dalam hal ini guru hendaknya mampu secara maksimal menunjukan kemampuan yang sebenarnya dengan lebih menunjukan figur dengan kepribadian guru di sertai tingkat kedewasaan yang matang, guru juga harus mampu memposisikan diri sebagai orang tua kedua bagi peserta didik, teman, sahabat juga lawan bicara yang menyenangkan sehingga sehingga membuat peserta didik merasa nyaman bila berhadapan dengan seorang guru.

Sekolah adalah merupakan suatu lembaga atau organisasi yang di dalamnya terdiri dari perangkat sistem yang terdiri dari pimpinan sekolah, guru yang bertinadak sebagai obyek pelaku dan pengelola administrasi serta orang Tua dari peserta didik yang menyekolahkan anaknya pada lembaga pendidikan tersebut. Sekolah sebagai penyedia pelayanan jasa pendidikan. Jadi yang dihasilkan oleh sekolah adalah jasa pelayanan, yang merupakan suatu produk yang tidak bisa dilihat atau diraba, tetapi dapat dirasakan manfaatnya oleh pemakai jasa. Asumsi tersebut disebabkan oleh jasa yang diberikan oleh sekolah adalah sebagai akibat dari pembayaran iuran peserta didik dalam menerima pembelajaran.

Menurut Berry (Alma, 2000; 205), ada 3 karakteristik jasa, yaitu : (a) Lebih bersifat tidak berwujud daripada berwujud (More intangible than tangible) ; (b) Produksi dan konsumsi bersamaan waktu (Simultaneous production and consumption) ; (c) Kurang memiliki standar dan keseragaman (Less standarized and uniform).

Salah satu faktor yang menentukan tingkat keberhasilan dan kualitas penyedia jasa adalah kemampuannya dalam memberikan pelayanan kepada pengguna jasa. Keberhasilan penyedia dalam memberikan layanan yang bermutu kepada pengguna jasa, pencapaian pangsa pasar yang tinggi serta peningkatan profit institusi sangat ditentukan oleh pendekatan yang digunakan. 
Service performance

Menurut American Sociaty for Quality Control (Nasution, 2001; 144), kualitas adalah keseluruhan ciri-ciri dan karakteristik-karakteristik dari suatu produk/jasa dalam hal kemampuannya untuk memenuhi kebutuhan-kebutuhan yang ditentukan atau bersifat laten. Didukung oleh Feigenbaum (Nasution, 2001; 16) bahwa kualitas adalah kepuasan pelanggan sepenuhnya (Full Customer Satisfaction). Suatu produk dikatakan berkualitas apabila dapat memberikan kepuasan sepenuhnya kepada konsumen, yaitu sesuai dengan apa yang diharapkan konsumen atas suatu produk.

Salah satu pendekatan kualitas pelayanan adalah model Service Quality. Service Quality dibangun atas adanya perbandingan dua faktor yaitu persepsi pelanggan atas layanan yang nyata mereka terima dengan layanan yang sesungguhnya diharapkan.

Menurut Kotler yang dikutip oleh Lupiyoadi (2001;148), ada lima dimensi kualitas pelayanan adalah sebagai berikut : (a) Tangibles atau bukti nyata yaitu kemampuan perusahaan dalam menunjukan eksistensinya kepada pihak internal ; (b) Realiability atau keandalan yaitu kemampuan perusahaan untuk memberikan pelayanan sesuai yang dijanjikan secara akurat dan terpercaya ; (c) Responsiveness atau daya tanggap yaitu suatu kemauan untuk membantu dan memberikan pelayanan yang cepat dan tepat kepada pelanggan dengan penyampaian informasi yang jelas ; (d) Assurance atau jaminan dan kepastian yaitu pengetahuan, kesopansantunan dan kemampuan para pegawai perusahaan untuk menumbuhkan rasa percaya para pelanggan kepada perusahaan ; (e) Empathy yaitu memberikan perhatian yang tulus dan bersifat individual atau pribadi yang diberikan kepada para pelanggan dengan berupaya memahami keinginan konsumen.

Dimensi pelayanan oleh penyedia jasa diupayakan dan dilaksanakan sebaik-baik mungkin, alasannya bahwa akan memotivasi dan menghasilkan kepercayaan dari peserta didik sehingga mereka akan selalu menggunakan jasa institusi berupa masih berperan aktif sebagai pengguna jasa yang nantinya merupakan pemasukan dana bagi institusi.

Perlu diketahui bahwa penyedia jasa berusaha menciptakan dan mempertahankan pelanggannya dengan menghasilkan dan menyampaikan jasa yang diinginkan pengguna jasa dengan harga yang pantas. Oleh karena itu, penyedia jasa harus mampu memahami perilaku pengguna jasa pada pasar sasarannya. Menurut Engel et. al (Tjiptono, 2000; 19), perilaku konsumen adalah tindakan-tindakan individu yang secara langsung terlibat dalam usaha memperoleh, menggunakan dan menentukan produk dan jasa termasuk proses pengambilan keputusan yang mendahului dan mengikuti tindakan-tindakan 
tersebut. Bila perusahaan dapat memahami perilaku konsumennya maka perusahaan dapat memberikan kepuasan secara lebih baik kepada konsumennya.

Service

performance

Menurut Day (Tjiptono, 2000;24), kepuasan dan ketidakpuasan pelanggan adalah respon pelanggan terhadap evaluasi ketidaksesuaian (disconfirmation) yang dirasakan antara harapan sebelumnya dan kinerja aktual produk yang dirasakan setelah pemakaiannya. Adapun menurut Engal, kepuasan pelanggan adalah evaluasi purnabeli di mana alternatif yang dipilih sekurang-kurangnya sama atau melampaui harapan pelanggan sedangkan ketidakpuasan timbul apabila hasil tidak memenuhi harapan. Menurut Kotler, kepuasan pelanggan adalah tingkat perasaan seseorang setelah membandingkan kinerja yang ia rasakan dibandingkan dengan harapannya.

\section{METODE PENELITIAN}

Pendekatan deskriptif dengan rancangan penelitian non-eksperimen dengan metode survei. Data primer diperoleh dari hasil wawancara dengan pimpinan sekolah, serta kuisioner yang langsung kepada orang tua dari peserta didik. Data sekunder berasal dari hasil meneliti berkas-berkas yang berhubungan dengan masalah yang diteliti.

Populasi dalam penelitian adalah seluruh peserta didik pada Sekolah Bina Bhakti Kabupaten Kubu Raya, menurut data perkembangan terakhir berjumlah 644 peserta didik. Sampel ditetapkan adalah orang tua dari peserta didik pada kelas akhir, artinya yang sudah menerima pelayanan atau sudah bekerjasama minimal dua tahun, penentuan besarnya sampel 100 orang tua peserta didik menurut Roscue (Sekaran, 2003).

Alat analisis data yang digunakan (Nasution, 2001; 56) adalah analisis tingkat kepentingan dan tingkat kinerja, serta Diagram Kartesius. Analisis tingkat kepentingan dan tingkat kinerja digunakan untuk melihat tingkat kepuasan peserta didik terhadap kinerja penyelenggara pendidikan pada Sekolah Bina Bhakti Kabupaten Kubu Raya. Skala Linkert digunakan sebagai konversi data kualitatif.

\section{HASIL PENELITIAN}

Tabel 1 Perhitungan Rata-Rata Dari Rata-Rata Persepsi Responden Terhadap Kinerja Pelayanan Sekolah Bina Bhakti Kabupaten Kubu Raya 
Service

performance

\begin{tabular}{|l|c|c|c|c|}
\hline \multicolumn{1}{|c|}{ Keterangan (kwadran) } & Xi & Yi & $\bar{X}$ & $\bar{Y}$ \\
\hline 1. Kemampuan memberikan pelayanan informasi (D) & 492 & 452 & 4.92 & 4.52 \\
2. Kualitas pengajar (B) & 496 & 490 & 4.96 & 4.90 \\
3. Validasi informasi yang diterima (B) & 488 & 510 & 4.88 & 5.10 \\
\hline 4. Waktu dan cara pembayaran iuran/SPP (C) & 462 & 342 & 4.62 & 3.42 \\
5. Cepat tanggap terhadap keluhan (A) & 466 & 512 & 4.66 & 5.12 \\
6. Kecepatan pelayanan petugas dan pengajar (A) & 480 & 520 & 4.80 & 5.20 \\
7. Kesediaan membantu penyelesaian keluhan (B) & 482 & 512 & 4.82 & 5.12 \\
\hline 8. Penampilan petugas dan pengajar (D) & 492 & 500 & 4.92 & 5.00 \\
9. Perilaku petugas dan pengajar (D) & 490 & 462 & 4.90 & 4.62 \\
10. Citra institusi / sekolah (B) & 520 & 480 & 5.20 & 4.80 \\
11. Jaminan keamanan (B) & 492 & 506 & 4.92 & 5.06 \\
\hline 12. Perhatian terhadap keluhan (A) & 454 & 480 & 4.54 & 4.80 \\
13. Kemudahan terhadap keinginan (A) & 420 & 500 & 4.20 & 5.00 \\
14. Fleksibelitas pembayaran iuran jika terlambat (C) & 460 & 384 & 4.60 & 3.84 \\
\hline 15. Kebersihan dan kerapian ruangan (B) & 489 & 474 & 4.89 & 4.74 \\
16. Fasilitas yang digunakan dalam pelayanan (B) & 497 & 500 & 4.87 & 5.00 \\
17. Suasana ruangan / kantor / kelas (B) & 4805 & 480 & 4.95 & 4.80 \\
18. Lokasi dan lahan parkir (B) & 8588 & 86.56 & 85.88 \\
\hline Jumlah & 477.11 & 4.81 & 4.77 \\
\hline Rata-rata & 4969 \\
\hline
\end{tabular}

Sumber : Data Olahan, 2017

Keterangan :

$\mathrm{Xi}=$ Skor Penilaian Tingkat Pelayanan

$\underline{Y i}=$ Skor Penilaian Tingkat Kepentingan

$\mathrm{X}=$ Rata-rata Tingkat Pelayanan 
Berdasarkan dari Tabel 1, maka peta penilaian responden terhadap kinerja pelayanan dapat digambarkan dalam diagram kartesius, yang dapat dilihat pada Gambar 1

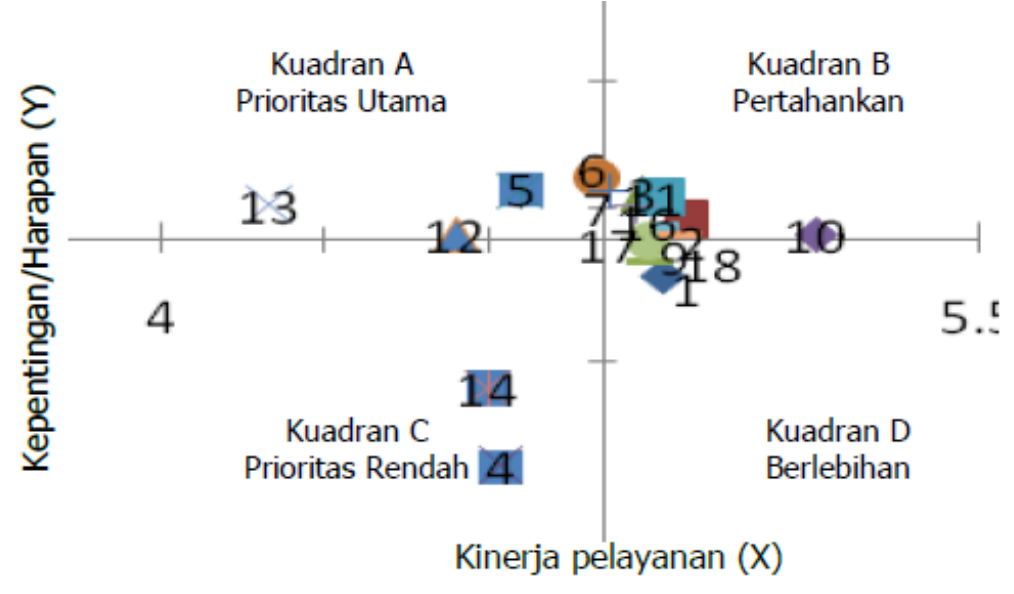

Gambar 1 : Diagram Kartesius Variabel-variabel Penelitian Yang Mempengaruhi Kinerja Pelayanan

Berdasarkan pendapat responden terhadap kinerja pelayanan, kemudian dilakukan Analisis kuantitatif yang merupakan rekapitulasi analisis faktor-faktor kinerja pelayanan terhadap Sekolah Bina Bhakti Kabupaten Kubu Raya . Variabel kinerja pelayanan meliputi : keandalan, daya tanggap, jaminan, empati dan keberwujudan. Kemudian untuk mempetakan posisi tingkat kepentingan/harapan responden dan tingkat kinerja penyelenggara pendidikan ditranspormasikan pada grafik kartesius, diperlukan skoring rata-rata setiap variabel tersebut. Perhitungan skoring dapat dilihat pada Tabel 1 dan pemetaanya pada Gambar 1.

\section{Pembahasan}

Berdasarkan diagram kartesius menunjukkan posisi tiap variabel penelitian, yang terbagi kedalam indikator atau instrumen penelitian. Adapun kondisi dari masing-masing indikator dan variabel penelitian yang dapat dijelaskan bahwa, variabel keandalan berupa kemampuan petugas dalam memberikan pelayanan informasi dan administrasi berada pada kuadran D, pelayanan dan kemampuan tenaga pengajar/petugas sudah sesuai dengan keinginan pelanggan dan institusi tidak perlu memfokuskan perbaikan pada kegiatan ini. Kualitas kinerja pelayanan berada pada kuadran B, mengindentifikasikan 
Service performance bahwa pengguna jasa menganggap hal ini sangat penting tetapi institusi sudah melakukan dengan baik sehingga prestasi ini perlu dipertahankan.

Variabel keandalan, kemampuan memberikan pelayanan informasi yang dilakukan institusi berada pada kuadran D dan telah dianggap pengguna jasa bahwa hal ini sangat penting dan institusi dapat memberikan pelayanan yang sangat berlebihan sehingga tidak perlu difokuskan tetapi tetap dipertahankan. Kualitas petugas dan serta validitas informasi yang diterima berada pada kuadran B, pengguna jasa mengangap hal ini cukup penting dan institusi dapat melakukan kegiatan ini dengan sangat baik sehingga pelayanan ini dianggap sangat baik dan institusi tidak perlu memfokuskan pada kegiatan ini tetapi tetap dipertahankan.

Variabel daya tanggap, kemampuan cepat tanggap tenaga pengajar/petugas dalam menangani keluhan serta kecepatan dalam pelayanan berada pada kuadran A artinya pengguna jasa mengharapkan yang lebih baik tetapi institusi belum optimal memberikan pelayanan sehingga pada kegiatan ini perlu diperhatikan dan difokuskan dalam memberikan pelayanan untuk perbaikan yang serius. Waktu dan cara pembayaran iuran/SPP berada pada kuadran C membuktikan bahwa pengguna jasa menganggap hal ini sangat penting tetapi belum dieksekusi dengan pelayanan yang optimal sehingga perlu menjadi perhatian untuk perbaikan. Kesediaan dalam membantu penyelesaian keluhan berada pada kuadran B artinya pengguna jasa manganggap hal ini sangat penting dan petugas/pengajar melakukannya dengan optimal sehingga pengguna jasa mengangap hal ini cukup penting sehingga pelayanan ini dianggap sangat baik dan institusi tidak perlu memfokuskan pada kegiatan ini tetapi tetap dipertahankan.

Variabel jaminan, penampilan tenaga pengajar/petugas dan perilaku petugas berada pada kuadran D, penilaian pengguna jasa sudah selayaknya dan mereka merasa puas dengan kinerja pelayanan institusi sehingga institusi tidak perlu memfokuskan kegiatan ini. Sedangkan citra sekolah dan jaminan terhadap keamanan perangkat sistem berada pada kuadaran $B$, artinya pengguna jasa menganggap hal ini sangat penting tetapi institusi sudah melakukannya dengan sangat baik dan sesuai dengan keinginan pengguna jasa. Menjadi perhatian institusi bahwa citra sekolah dan jaminan keamanan sistem tersebut harus tetap dipertahankan prestasinya oleh institusi.

Variabel empati, perhatian petugas terhadap keluhan, kemudahan terhadap keluhan berada pada kuadran A artinya pengguna jasa mengharapkan yang lebih baik tetapi 
institusi belum optimal memberikan pelayanan sehingga pada kegiatan ini perlu diperhatikan dan difokuskan dalam memberikan pelayanan untuk perbaikan yang serius.

Service performance

Fleksibelitas saat pembayaran iuran terlambat semuanya berada pada kuadran C, menandakan bahwa petugas dalam bekerja masih belum setulus hati melayani pengguna jasa. Pelayanan yang dilakukan oleh petugas menurut standar kerja, pengguna jasa menilai hal ini sangat penting sehingga harapan mereka masih belum terpenuhi dengan baik. Oleh karena itu institusi menekankan pada hal ini dengan lebih serius dan menjadi prioritas dalam perbaikannya.

Variabel keberwujudan, kebersihan/kerapian ruangan, penggunaan fasilitas dalam pelayanan, suasana ruangan, dan lokasi/luas parkir berada pada kuadran B. Pengguna jasa menilai bahwa pelayanan ini cukup penting dan institusi dapat melayani dengan sangat baik sehingga kinerja pelayanan institusi sudah memadai dan pelayanan ini selalu dipertahankan prestasinya oleh institusi.

\section{KESIMPULAN}

Berdasarkan diagram kartesius, variabel penelitian perlu mendapat prioritas perbaikan oleh institusi adalah ; kemampuan cepat tanggap petugas terhadap keluhan; kemudahan / kecepatan pelayanan petugas; perhatian petugas terhadap keluhan; kemudahan dalam pemenuhan keinginan pengguna jasa merupakan prioritas utama yang perlu diperbaiki. Posisi variabel lain yang perlu diperhatikan juga adalah waktu pembayaran iuran dan fleksibelitas pembayaran jika terjadi keterlambatan.

\section{Saran}

Sebaiknya institusi lebih menekankan pada pelayanan bersifat empati kepada pengguna jasa, peningkatan pelayanan harus berbasis kepentingan pengguna jasa dan mementingkan nilai-nilai kepedulian terhadap pengguna jasa.

Berdasarkan pemetaan diagram kartesius, prioritas perbaikan pada variabelvariabel penelitian yang berada pada kuadran A dan kuadran C, sehingga institusi sebaiknya melakukan hal-hal sebagai berikut: 1) Perlunya unit yang khusus melakukan tugas pelayanan yang cepat sehingga keperluan/keluhan pengguna jasa di lapangan dapat 
Service

performance dilayani dengan segera ; 2) Meningkatan kualitas sumberdaya dengan pelatihan-pelatihan atau CD-Room yang berhubungan dengan pelayanan empati terhadap pengguna jasa.

\section{Daftar Pustaka}

Alma, Buchari, Manajemen Pemasaran dan Pemasaran Jasa Edisi Revisi, Penerbit Alfabet, Bandung, 2000.

Ibrahim, Buddy, TQM (Total Quality Management) Panduan untuk Menghadapi Persaingan Global, Penerbit Djambatan, Jakarta, 1997.

Kotler, Philip dan Gary Armstrong, Dasar-dasar Pemasaran Jilid 2 Edisi Bahasa Indonesia dari Principles of Marketing 7e, Penerbit Prenhallindo, Jakarta, 1998.

Kotler, Philip, Manajemen Pemasaran untuk Analisis, Perencanaan, Implementasi dan Kontrol Edisi Bahasa Indonesia Jilid 2, Penerbit PT Prenhallindo, Jakarta, 1997.

Kotler, Philip, Swee Hoon Ang, Siew Meng Leong dan Chin Tiong Tan, Manajemen Pemasaran Perspektif Asia Buku 2, Penerbit Andi, Yogyakarta, 2000.

Lupiyoadi, Rambat, Manajemen Pemasaran Jasa, Penerbit Salemba Empat, 2001.

Marzuki, Metodologi Riset, Penerbit BPFE-UII, Yogyakarta, 1996.

Nasution, M. N., Manajemen Mutu Terpadu (Total Quality Management), Penerbit Ghalia Indonesia, Jakarta, 2001. , Manajemen Transportasi, Penerbit Ghalia Indonesia, Jakarta, 1996.

Robbins, Stephen P., Perilaku Organisasi Konsep, Kontroversi dan Aplikasi Edisi Bahasa Indonesia Jilid I, Penerbit PT Prenhallindo, Jakarta, 1996.

Singarimbun, Masri dan Sofian Effendi, Metodologi Penelitian, Penerbit Erlangga, Jakarta, 1996.

Sugiyono, 1999, Metode Penelitian Administrasi, Alfabeta, Bandung Sugiyono,2003, Metode Penelitian Administrasi, Alfabeta, Bandung. Sumadi Suryabrata, 2004, Metode Penelitian, Rajawali Press, Jakarta. 
Tjiptono, Fandy, Strategi Pemasaran, Penerbit Andi, Yogyakarta, 2000.

Umar, Husein, Metode Penelitian untuk Skripsi dan Tesis Bisnis, Penerbit PT Raja

Grafindo Persada, Jakarta, 2003. 